\title{
Overview of Bifluid-based Photovoltaic Thermal (PVT) Systems
}

\author{
Nurul Shahirah Binti Rukman, Ahmad Fudholi, Saleem H. Zaidi, Kamaruzzaman Sopian \\ Solar Energy Research Institute, Universiti Kebangsaan Malaysia, Bangi Selangor, Malaysia
}

\begin{tabular}{l} 
Article Info \\
\hline Article history: \\
Received Aug 15, 2018 \\
Revised Sep 6, 2018 \\
Accepted Sep 11, 2018 \\
\hline
\end{tabular}

Keyword:

Efficiency

Energy analysis

Photovoltaic

Renewable energy

Solar energy

\begin{abstract}
This review presents various research and development, as well as design and performances of bifluid-based PVT systems. Moreover, the development of PVT system is a very promising area of research. PVT systems using in various applications, such as solar drying, solar cooling, water heating, desalination, and pool heating. With the recognition of the potentials and contributions of PV system, considerable research has been conducted to attain the most advancement which may produce reliable and sustainable PVT system. The cooling system's design refers to the absorber design which mostly focuses on water and air-based PVT systems. An air-based system has been developed through different absorber configurations, air flow modes and single- or double-pass design. Bifluid-based PVT system is used to remove heat accumulated in a PV panel and reuses the waste heat (hot air and water) in an appropriate way. PV, thermal and PVT efficiencies of bifluid PVT systems were $6.6 \%-18.6 \%, 31 \%-90 \%$ and $60 \%-83 \%$, respectively.
\end{abstract}

Copyright $\odot 2018$ Institute of Advanced Engineering and Science. All rights reserved.

\section{Corresponding Author:}

Ahmad Fudholi,

Solar Energy Research Institute, Universiti Kebangsaan Malaysia,

43600 Bangi Selangor, Malaysia.

Email: a.fudholi@ukm.edu.my

\section{INTRODUCTION}

Noted from the current issues on energy demand on expensive cost of conventional fuels, the usage of solar energy has been choosen as an alternative way for the energy source. Due to its feasibility and how the beneficial may economically aids the energy demand for most of application nowadays; such as drying of Currently, conventional fuels are scarce and expensive, and its future cost and availability are uncertain. Hence, the usage of solar energy in drying of agronomic products, promising a great way in its role as the source of energy. Photovoltaic (PV) panel is the most outistanding technology in generating electrical energy which converts the sulight or solar radiation opon the panel. Recent advancements of PV studies has introduced photovoltaic thermal (PVT) system which can produce thermal energy besides the production of electricity continuously from one combined system. It consists of PV panel, insulation and cooling system which utilizing fluids. Thus, as the panel absorbs the sunlight, the heat from the panel will be extracted in order to prevent extra hot temperature which may influence the performance of the system. The coolants or working fluids used will produce hot air or hot water and both if these had been used in same operation [1]-[13].

The PVT system had improved the electrical deficiency of the PV system as heat from the panel had been extracted. The studies on PVT system had been anticipated by lots of researchers which intended to study on how it can contribute its performances in generating both electrical and heat energy. A review on list of studies conducted had focused on various climatic, design and operational restrictions of PVT system's performances. Single system of water and air-based PVT distinguished by the flow pattern of them which defined on the design of cooling system itself [14]. Recently, analysis on PVT performances had been furthered to assess the economic and environmental yield as conducted [15]. In this review, describe of bifluid (air and water)-based PVT systems is presented. Also, energy and other analysis of bifluid-based PVT systems are presented. 


\section{TYPES OF BIFLUID-BASED PVT SYSTEMS}

PVT is the popular system of a solar energy system. A bifluid-based PVT system is designed to receive solar energy and convert it into electrical and thermal (hot air and water); in this device, thermal is transferred into air and water that flows into the collector. A bifluid-based PVT system consists of a PV panel, air channel, pipe/riser, insulation and a frame as well as one or more glass cover or a transparent material placed over the absorbing plate with air and water flowing around it. Bifluid-based PVT systems can be categorised into four types are: (i) single-pass without glass cover as shown in Figure 1a, (ii) single-pass with glass cover as shown in Figure 1b, double-pass without thermal storage as shown in Figure 1c, and double-pass with thermal storage as shown in Figure 1d.

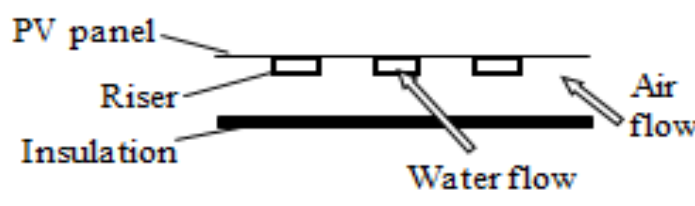

(a)

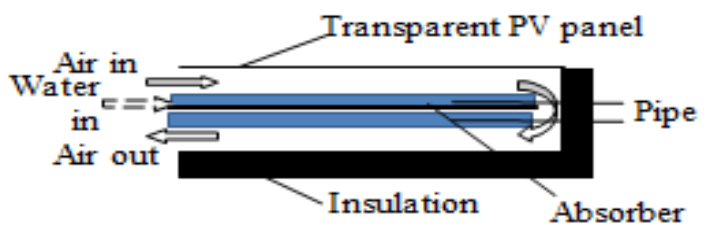

(c)

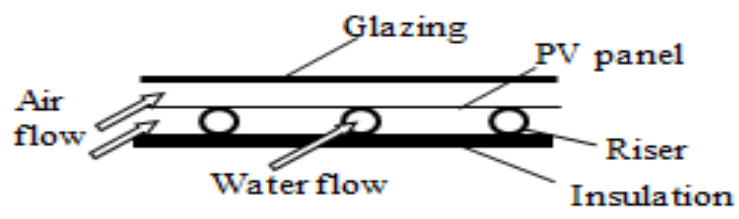

(b)

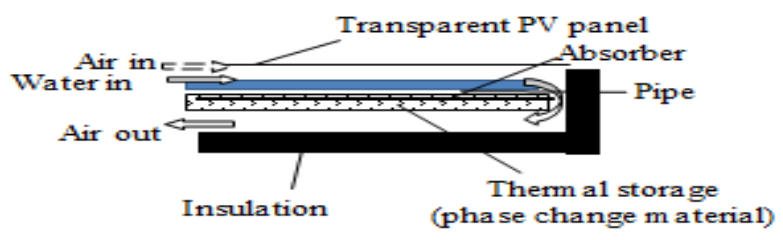

(d)

Figure 1. Bifluid-based PVT Systems; (a) Single-pass without glass cover, (b) Single-pass with glass cover, (c) Double-pass without thermal storage, (d) Double-pass with thermal storage

\section{STUDIES CONDUCTED ON BIFLUID-BASED PVT SYSTEMS}

The employment of both water and air in a single PVT system leads to the increment in the overall efficiency per unit area and it had been assumed that to be higher compared to the conventional solar collector even with same area of collector. They were predicted as being complement one as the fluids will be operated concurrently [16].

In order to produce hot water, hot air and electricity simultaneously, PVT system had employed both air and water as coolants. This integration of heat removal had been known as bifluid-based PVT system which able to overcome limitations of using both of them as single coolant [17].

Assoa et al. [18] have also carried out studies on the use of bifluid PVT system. A quasi 2D analysis was carried out and as for the collector design, the position of the thermal component of the collector and PV sectors alternates which results in high temperature of water production without a penalty in the electricity production. A good agreement between the theoretical and experimental results was obtained.

An integration of a PV panel, serpentine-shaped-copper tube and a single pass air channel is proposed thus bi-fluid were utilized as the working fluids. By considering a few design and environmental parameters, simulations are carried out and efficiencies curves are calculated using a numerical model. The simulations show that, the satisfactory overall performance is achieved when the fluids are operated independently and higher when operated instantaneously. It had been concluded that the technical and commercial feasibilities which involve experimental fabrication [19].

A design in improving bifluid PVT system had been proposed in 2014. Satisfactory result had been obtained on thermal, electrical and equivalent thermal efficiency for independent fluid and simultaneous fluid. 76\% of equivalent thermal efficiency obtained at the optimal mass flow rate [20].

A hybrid PVT system with transparent PV panel was used and mounted on the top of designed system, by validating Hottel-Whillier Bliss equation for evaluating system performance. Attaining result from the study were $17 \%$ and $76 \%$ respectively of electrical and total thermal efficiency at irradiance of 800 $\mathrm{W} / \mathrm{m}^{2}$ with $0.05 \mathrm{~kg} / \mathrm{s}$ and $0.02 \mathrm{~kg} / \mathrm{s}$ optimum flow rate of air and water respectively [21].

$\mathrm{Su}$ et al. [22] conducted numerical study on the performance of double channel PVT system. From this research, it had been observed that this designated PVT system attained great performance in generating 
both electrical and thermal energy. Table 1 shows R\&D of bifluid-based PVT systems. Energy and exergy analysis of bifluid-based PVT systems by different researchers as shown in Table 2.

Table 1. R\&D of Bifluid-based PVT Systems

\begin{tabular}{|c|c|c|c|}
\hline Year & Reference & Implemented Approaches & Research Findings \\
\hline 2013 & [19] & $\begin{array}{l}\text { Serpentine shaped copper tube with } \\
\text { single-pass air passage }\end{array}$ & $\begin{array}{l}\text { Satisfactory overall performance is } \\
\text { achieved }\end{array}$ \\
\hline 2014 & {$[20]$} & Simulation study & $\begin{array}{l}\text { Equivalent thermal efficiency is } \\
76 \% \text { at optimal mass flow rate. }\end{array}$ \\
\hline 2016 & [21] & $\begin{array}{l}\text { Integration of Hottel-Whillier Bliss } \\
\text { equation }\end{array}$ & $\begin{array}{l}\text { At } 800 \mathrm{~W} / \mathrm{m}^{2} \text { and } 0.05 \mathrm{~kg} / \mathrm{s} \text {, } \\
\text { electrical efficiency is } 17 \% \text { and } \\
\text { total thermal efficiency is } 76 \% \text {. }\end{array}$ \\
\hline 2016 & {$[22]$} & $\begin{array}{l}\text { Numerical model was established and } \\
\text { simulated using MATLAB }\end{array}$ & $\begin{array}{l}\text { Optimum electrical efficiency is } \\
7.8 \% \text { and overall efficiency is } \\
84.2 \%\end{array}$ \\
\hline
\end{tabular}

Table 2. Performance of Bifluid-based PVT Systems

\begin{tabular}{|c|c|c|c|c|c|c|c|}
\hline \multirow{2}{*}{ Year } & \multirow{2}{*}{ Author(s) } & \multirow{2}{*}{ Study } & \multirow{2}{*}{$\begin{array}{c}\text { Performance } \\
\text { Analyses }\end{array}$} & \multicolumn{3}{|c|}{ Energy Efficiencies (\%) } & \multirow{2}{*}{$\begin{array}{c}\text { PVT Exergy } \\
\text { Efficiency }(\%)\end{array}$} \\
\hline & & & & $\mathrm{PV}$ & Thermal & Overall & \\
\hline 2002 & Staebler et al. [23] & Experimental & Energy analysis & 18.6 & 32.5 & NA & NA \\
\hline 2003 & Zondag et al. [24] & Experimental & Energy analysis & 9.7 & 83 & NA & NA \\
\hline 2005 & Rosell et al. [25] & $\begin{array}{l}\text { Experimental } \\
\text { and theoretical }\end{array}$ & Energy analysis & 10.2 & NA & 60 & NA \\
\hline 2006 & $\begin{array}{l}\text { Tiwari and Sodha } \\
\text { [26] }\end{array}$ & $\begin{array}{l}\text { Experimental } \\
\text { and theoretical }\end{array}$ & Energy analysis & NA & NA & $65-77$ & NA \\
\hline 2007 & Assoa et al. [18] & $\begin{array}{l}\text { Experimental } \\
\text { and theoretical }\end{array}$ & Energy analysis & NA & 80 & NA & NA \\
\hline 2014 & $\begin{array}{l}\text { Abu Bakar et al. } \\
{[20]}\end{array}$ & $\begin{array}{l}\text { Experimental } \\
\text { and theoretical }\end{array}$ & Energy analysis & $10.6-11.1$ & $31-42.7$ & $61.8-78.8$ & NA \\
\hline 2015 & Li et al. [27] & Experimental & Energy analysis & 6.6 & 52 & 65.5 & NA \\
\hline 2016 & Su et al. [22] & Experimental & Energy analysis & 11.8 & 64.4 & $80-83$ & NA \\
\hline 2016 & Othman et al. [28] & $\begin{array}{l}\text { Experimental } \\
\text { and theoretical }\end{array}$ & Energy analysis & 17 & 76 & NA & NA \\
\hline 2017 & Baljit et al. [29] & $\begin{array}{l}\text { Experimental } \\
\text { and theoretical }\end{array}$ & Energy analysis & $12.3-13.5$ & $63-90$ & NA & NA \\
\hline
\end{tabular}

\section{INSTALLATIONS OF PVT SYSTEMS}

There are lots of employment from previous PVT studies that had been adapted in recent applications such as for building, solar distillation, thermoelectric generator and heat pump [30]. A compound parabolic concentrator (CPC)'s based roof; PVT with daylight system had been proposed. This study covered great absorption of sunlight and as it influenced the increment of indoor temperature, suction pump has been used as temperature regulator [31].

BIPVT system has been developed further on convective heat transfer coefficient which correlating on top and bottom of PV panel, adequately by force convection [32]. An optimization has been conducted which connected PVT air collector to the air distribution system of residential building. From the experiment, the smaller collector depth offered good performance for large temperature difference. However, the design acted important role as it influenced changes in ratio of mass flow rate and collector area.

A performance of BIPVT system has been analyzed for residential application which modeling and simulation of different building layout. As resulted from conducted analysis, both energy and economic term has been assessed [33].

Integration of thermoelectric generator and heat pump contributed to alternate chances in supplying hot water mostly for building applications. A novel model of using heat pump for water heating has been proposed, comprising a PV/T collector with micro heat pipe arrangement. In the meantime, this proposed study had solved the issue of air-based heat pump which frosted under cold climate season, by using an evaporator [34]. 


\section{CONCLUSIONS}

Bifluid-based PVT system combines the PV panel and solar collector into a single module, thereby enabling PV-cell cooling and simultaneously utilising the extracted heat for domestic use. PV, thermal and PVT efficiencies of bifluid PVT systems were 6.6\%-18.6\%, 31\%-90\% and 60\%-83\%, respectively.

\section{ACKNOWLEDGEMENTS}

The authors would like to thank the UKM for funding (DLP/1/2015/ST02/UKM/03/1) and (GGP-2017-045).

\section{REFERENCES}

[1] N.S. Nazri, et al., "Energy economic analysis of photovoltaic-thermal-thermoelectric (PVT-TE) air collectors. Renewable and Sustainable Energy Review, vol. 92, pp. 187-97, 2018.

[2] N.S. Nazri, et al., "Mathematical modeling of photovoltaic thermal-thermoelectric (PVT-TE) air collector. International Journal of Power Electronics and Drive Systems (IJPEDS), vol. 9, no. 2, pp. 795-802, 2018.

[3] M. Zohri, et al., "Photovoltaic thermal (PVT) system with and without fins collector: theoretical approach. International Journal of Power Electronics and Drive System (IJPEDS), vol. 8, no. 4, pp. 1756-63, 2017.

[4] A. Fudholi, et al., "Review on exergy and energy analysis of solar air heater. International Journal of Power Electronics and Drive Systems (IJPEDS), vol. 9, no. 1, pp. 420-26, 2018.

[5] A. Fudholi, et al., "Review on solar collector for agricultural produce. International Journal of Power Electronics and Drive Systems (IJPEDS), vol. 9, no. 1, pp. 414-19, 2018.

[6] A. Fudholi, et al., "R\&D of photovoltaic thermal (PVT) systems: an overview. International Journal of Power Electronics and Drive Systems (IJPEDS), vol. 9(2), pp. 803-10, 2018.

[7] A. Fudholi, et al., "Primary study of tracking photovoltaic system for mobile station in Malaysia. International Journal of Power Electronics and Drive Systems (IJPEDS), vol. 9(1), pp. 427-32, 2018.

[8] A. Fudholi, et al., "Design and testing of solar dryer for drying kinetics of seaweed in Malaysia," in Proc. of the 5th Int. Conf. on Energy and Development- Environment - Biomedicine (EDEP'11, Corfu, 2011, pp. 119-124.

[9] C.N. Aisyah et al., "Kecekapan pengumpul PV/T menggunakan pengumpul terma reka bentuk pilin (Efficiency of PV/T collector using spiral thermal absorber design), Sains Malaysiana, vol. 47, no. 4, pp. 853-859, 2018.

[10] A. Fudholi, et al., "Energy and exergy analyses of photovoltaic thermal collector with $\nabla$-groove," Solar Energy, vol. 159 , pp. 742-50, 2018.

[11] A. Fudholi, et al., "Performance analysis of photovoltaic thermal (PVT) water collectors,"Energy Conversion and Management, vol. 78, pp. 641-651, 2014.

[12] M. Zohri, et al., "Exergy assessment of photovoltaic thermal with v-groove collector using theoretical study. TELKOMNIKA, vol. 16(2), pp. 550-57, 2018.

[13] A. Ibrahim et al., "Efficiencies and improvement potential of building integrated photovoltaic thermal (BIPVT) system," Energy Conversion and Management, vol. 77, pp. 527-34, 2014.

[14] A. Ibrahim et al, "Recent advances in flat plate photovoltaic/thermal (PV/T) solar collectors," Renewable and Sustainable Energy Reviews, vol. 15, no. 1, pp. 352-365, 2011.

[15] M. J. Adedeji et al, "Energy, Exergy, Economic and Environmental analysis of Photovoltaic Thermal Systems for Absorption Cooling Application," Energy Procedia, vol. 142, pp. 916-923, 2017.

[16] L. Xia et al, "A model-based optimal control strategy for ground source heat pump systems with integrated solar photovoltaic thermal collectors," Applied Energy, vol. 228, pp. 1399-1412, 2018.

[17] Y. Tripanagnostopoulos, "Aspects and improvements of hybrid photovoltaic/thermal solar energy systems," Solar Energy, vol. 81, no. 9, pp. 1117-1131, 2007.

[18] Y. B. Assoa et al, "Study of a new concept of photovoltaic-thermal hybrid collector," Solar Energy, vol. 81, no. 9, pp. 1132-1143, 2007.

[19] M. Nazari et al., "Development of an improved photovoltaic/thermal (PV/T) solar collector with bi-fluid configuration," International Journal of Chemical and Environmental Engineering, vol. 4, no. 4, 2013.

[20] M. N. Abu Bakar et al, "Design concept and mathematical model of a bi-fluid photovoltaic/thermal (PV/T) solar collector," Renewable Energy, vol. 67, pp. 153-164, 2014.

[21] M. Y. Othman et al, "Performance analysis of PV/T Combi with water and air heating system: An experimental study," Renewable Energy, vol. 86, pp. 716-722, 2016.

[22] D. Su et al, "Dynamic performance analysis of photovoltaic-thermal solar collector with dual channels for different fluids," Energy Conversion and Management, vol. 120, pp. 13-24, 2016.

[23] D. L. Staebler et al, "Development of high efficiency hybrid PV-thermal modules," in Conference Record of the Twenty-Ninth IEEE Photovoltaic Specialists Conference, pp. 1660-1663, 2002.

[24] H. A. Zondag et al, "The yield of different combined PV-thermal collector designs," Solar Energy, vol. 74, no. 3, pp. 253-269, 2003.

[25] J. I. Rosell et al, "Design and simulation of a low concentrating photovoltaic/thermal system," Energy Conversion and Management, vol. 46, no. 18-19, pp. 3034-3046, 2005.

[26] A. Tiwari and M. S. Sodha, "Performance evaluation of solar PV/T system: An experimental validation," Solar Energy, vol. 80, no. 7, pp. 751-759, 2006. 
[27] G. Li et al, "Outdoor overall performance of a novel air-gap-lens-walled compound parabolic concentrator (ALCPC) incorporated with photovoltaic/thermal system," Applied Energy, vol. 144, pp. 214-223, 2015.

[28] M. Y. Othman et al, "Performance analysis of PV/T Combi with water and air heating system: An experimental study," Renewable Energy, vol. 86, pp. 716-722, 2016.

[29] S. S. S. Baljit et al., "Mathematical modelling of a dual-fluid concentrating photovoltaic-thermal (PV-T) solar collector," Renewable Energy, vol. 114, pp. 1258-1271, 2017.

[30] A. Chauhan et al., "Futuristic approach for thermal management in solar PV/thermal systems with possible applications, "Energy Conversion and Management, vol 163, pp. 314-354, 2018.

[31] C. Feng et al., " A novel solar multifunctional PV/T/D system for green building roofs," Energy Conversion and Management vol 93, pp 63-71, 2015.

[32] Candanedo et al., "Convective heat transfer coefficients in a building-integrated photovoltaic/thermal system," Journal of Solar Energy Engineering vol 133(2), pp:021002, 2011.

[33] Buonomano A et al., "BIPVT systems for residential applications: An energy and economic analysis for European climates," Applied Energy vol 184, pp: 1411-1431, 2016.

[34] Wang, G et al., "Experimental study of a novel PV/T-air composite heat pump hot water system, " Energy Procedia vol 70, pp: 537-543, 2015.

\section{BIOGRAPHIES OF AUTHORS}

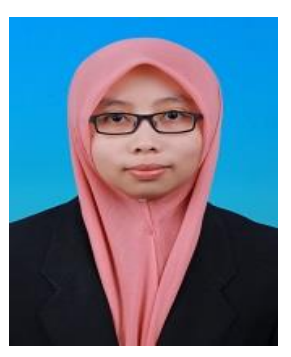

Nurul Shahirah binti Rukman, graduated in bachelor degree of Applied Physics from Universiti Sains Islam Malaysia (USIM) 2017. Focusing on PVT energy generation during her final year study had influenced her to further the study of PVT technology system. Currently, has been under supervison of Dr Ahmad Fudholi for her Master degree (Renewable Energy), on exergyenvironmental-economic analysis of bi-fluid PVT system.

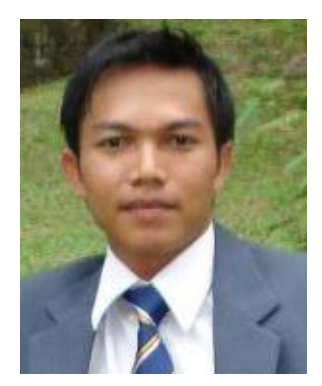

Ahmad Fudholi, Ph.D, M.Sc obtained his S.Si (2002) in physics. He was born in 1980 in Pekanbaru, Indonesia. He served as was the Head of the Physics Department at Rab University Pekanbaru, Riau, Indonesia, for four years (2004-2008). A. Fudholi started his master course in Energy Technology (2005-2007) at Universiti Kebangsaan Malaysia (UKM). After obtaining his Master's, he became a research assistant at UKM until. After his Ph.D (2012) in renewable energy, he became postdoctoral in the Solar Energy Research Institute (SERI) UKM until 2013. He joined the SERI as a lecturer in 2014. He received more than USD 389,000 worth of research grant (16 grant/project) in 2014-2018. He supervised and completed more than $27 \mathrm{M}$.Sc projects. To date, he has managed to supervise five $\mathrm{Ph} . \mathrm{D}$ (seven as main supervisors and one as co-supervisor), three Master's student by research mode and five Master's student by coursework mode. He was also an examiner (three Ph.D and one M.Sc). His current research focus is renewable energy, particularly solar energy technology, micropower systems, solar drying systems and advanced solar thermal systems (solar-assisted drying, solar heat pumps, PVT systems). He has published more than 120 peer-reviewed papers, of which 25 papers are in the ISI index ( 20 Q1, impact factor more than 4) and more than 70 papers are in the Scopus index. He has 16 currently accepted manuscripts, 20 manuscripts currently under review and two book chapters. In addition, he has published more than 70 papers in international conferences. He has a total citations of 854 and a h-index of 15 in Scopus (Author ID: 57195432490). He has a total citations of 1493 and a h-index of 20 in Google Scholar. He has been appointed as reviewer of high-impact (Q1) journals. He has also been appointed as editor of journals. He has received several international awards. He has also been invited as speaker in the Workshop of Scientific Journal Writing; Writing Scientific Papers Steps Towards Successful Publish in High Impact (Q1) Journals. He owns one patent and two copyrights.

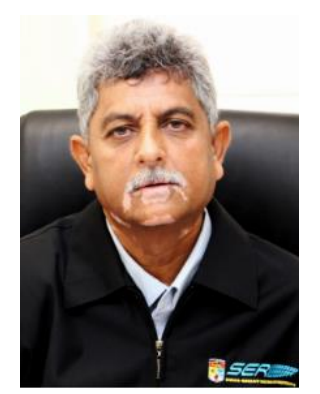

Prof Dr. Saleem H. Zaidi obtained his B.Sc in physics (Quaid-i-Azam University, Islamaband, Pakistan). He was obtained his M.Sc (Michigan State, East Lansing, Michigan, USA) and Ph.D (University of New Mexico, Albuquerque, NM, USA) in physics. His research interest includes Silicon nano and micro structures, crystalline mono and bifacial solar cells, advanced thin- film silicon Solar Cell, heteoepitaxial growth on $\mathrm{Si}$, SixGe1-x solar cells, low temperature solar cell processing, solar panel manufacturing, optical output enhancement in solar cells, solar cell characterzzation systems (LIV, SPV, SR, EQE, 4-point, contact resistivity) and optical methods to enhance heating from sunlight for heat and electricity generation. He has a total citations of 1153 and a h-index of 17 in Scopus (Author ID: 7101670320). He has a total citations of 3870 and a h-index of 33 in Google Scholar. He has published more than 240 peer-reviewed papers. 


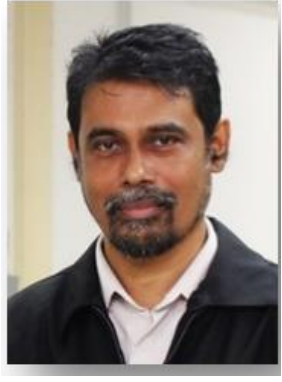

Prof Dato' Dr. Kamaruzzaman Sopian graduated with BS Mechanical Engineering at the University of Wisconsin-Madison in 1985, MS in Energy Resources at the University of Pittsburgh in 1989 and $\mathrm{PhD}$ in Mechanical Engineering at the Dorgan Solar Laboratory, University of Miami at Coral Gables in 1997. He has been involved in the field of renewable energy for more than 25 years. He has secured research funding of more than USD 6 million from the Malaysian Minstry of Science and the Malaysian Ministry of Education as well as from the industry. He has conducted renewable energy courses in the Asian School of Energy (20072014), which was funded by ISESCO, COMSAT, TIKA and UNESCO. He has published over 800 papers in journals and conferences (SCOPUS h index $=53$, no. of citations $=9610$; Google Scholar $\mathrm{h}$ index=66, no. of citations=15912). He supervised and completed $32 \mathrm{MSc}$ (coursework), $15 \mathrm{MSc}$ (research mode) and $40 \mathrm{PhD}$ students. 